\title{
Merayakan Kelahiran Bromartani
}

\author{
Oleh: Wendi Ahmad Wabyudi
}

Ungkin tak banyak tahu bahwa pada hari ini, tepatnya 123 tahun yang lalu.
Sebuah catatan sejarah digoreskan. Memang bukan sebuah peristiwa yang sangat berpengaruh dalam lahirnya Indonesia sebagai sebuah negara bangsa dikemudian hari. Tapi catatan sejarah ini penting bagi perjalanan pers di Indonesia. Penggores catatan sejarah tersebut dilakukan oleh Bromartani yang menjadi surat kabar pertama di Indonesia-Hindia Belanda pada saat itu-yang terbit dalam bahasa pribumi. Surat kabar ini terbit dalam bahasa Jawa.

Memang namanya tak segaung Bintang Hindia, Bintang Timoer, atau Medan Prijaji dalam cerita sejarah pers Indonesia. Hal itu (mungkin) bisa sedikit dimaklumi, karena memang pendiri surat kabar tersebut bukanlah seorang pribumi. Tetapi malah didirikan oleh seorang Belanda totok. Namun, jika membicarakan surat kabar berbahasa pribumi, Bromartani lah yang menggoreskan tinta sejarah itu pertama kali.

Untuk mengenang "Sang Pionir" ini, alangkah lebih baiknya kita kembali menulis kisahnya kembali. Menikmati sajian sejarah memang terkadang sangat membosankan bagi kebanyakan orang, terutama bagi generasi milineal-ini hanya sekedar dugaan, mudah-mudahan saja tidak demikian. Tapi pituah Presiden pertama Republik Indonesia Soekarno, perlu rasanya direnungkan. "Bahwa janganlah melihat ke masa depan dengan mata buta. Masa yang lampau berguna sekali untuk menjadi kaca benggala untuk masa yang akan datang." Mudah-mudahan kisah "Sang Pionir" bias menjadi bagian dari pituah tersebut.

\section{Sang Pionir}

romartani merupakan surat kabar berbahasa pribumi pertama dalam sejarah
panjang dunia pers Indonesia. Terbit pertama kali pada tanggal 25 Januari 1855. Surat kabar ini dikelola oleh Belanda totok C.F. Winter Sr. bersama dengan putranya Gustaff Winter, terbit dalam bahasa Jawa. Bromartani terbit secara mingguan-tepatnya setiap hari Kamis-dari percetakan Hartevelt di Surakarta. Percetakan Hartevelt juga 
memberikan modal sebesar 400 gulden untuk penerbitan dan pengelolaan surat kabar ini.

Kehadiran Bromartani tak terlepas dari dikeluarkannya UU tahun 1954 (Regeerings Reglement) yang secara tersirat memberikan kelonggaran pada peraturan pers di Hindia Belanda. Lebih tepatnya merupakan janji kemerdekaan pers. Janji yang pada akhirnya baru ditepati dua tahun setelah Regeerings Reglement dikeluarkan atau setelah Bromartani merayakan setahun usianya. Janji itu berwujud pada UU Pers 1856 (Drukpersreglement).

Terbitan tertanggal 25 Januari 1855 merupakan edisi uji coba Bromartani. Pada saat itu, penerbitan edisi uji coba merupakan sebuah kelumrahan. Hal ini biasanya digunakan untuk mengukur respon calon pembaca dan mencari pelanggan. Setelah dua bulan diterbitkan edisi uji coba tersebut, barulah edisi reguler Bromartani untuk pertama kali diterbitkan. Tepatnya pada tanggal 29 Maret 1885. Untuk berlangganan surat kabar ini dikenai biaya sebesar 12 gulden.

Kemunculan Bromartani bertepatan dengan keberadaan Surakarta yang pada saat itu sebagai pusat penyebaran pendidikan model Eropa di kalangan anak-anak bangsawan Jawa. Maka tidak heran jika Winter menyediakan ruang yang cukup besar untuk mengisi halaman-halaman berita terkait pendidikan dan juga sastra, karena memang salah satu target pembaca yang dituju Winter adalah anak-anak sekolah. Pada rubrik sastra, Ronggowarsito yang merupakan penyair terkenal Jawa menjadi penulis rutinnya, bahkan ia juga menjabat sebagai salah satu dewan redaksinya.

Selain menyasar anak-anak sekolah, Bromartani juga menyasar pembaca umum. Untuk hal ini, Bromartani menyediakan tulisan-tulisan dengan tema beragam seperti berita kelahiran dan kematian, lelang ikan, obral barang, perkembangan industri, pergantian pejabat, jadwal keberangkatan dan kedatangan kapal, termasuk juga berita berita-berita mengenai kejadian yang berada di sekitar Surakarta. Tak luput juga berita tentang Keraton Ngayogyakarta Hadiningrat, seperti penobatan Sultan Yogyakarta yang baru pada tahun 1856, yaitu Sultan Hamengku Buwono IV. (Adam, 1995: 33)

Bahkan menurut D.A. Rinkes (dalam Utomo, 2015), seorang penasihat urusan pribumi pemerintah Belanda, mengatakan bahwa, "Surat kabar ini menjadi sura kabar keraton yang berisi tentang pengangkatan dan pemindahan pegawai- 
pegawai keraton, dari orang-orang magang bergaji 2,5 gulden sampai pegawai tinggi yang bergaji 600 gulden sebulan. Pada umumnya surat kabar ini loyal terhadap pemerintah."

Usia surat kabar Bromartani hanya bertahan kurang dari dua tahun. Edisi terakhirnya terbit sebulan sebelum ulang tahunnya yang kedua. Tepatnya pada tanggal 23 Desember 1856. Penghentian penerbitan Bromartani disebabkan oleh jumlah pelanggan yang terus stagnan di bawah angka 300. Secara bisnis, ini tidak menguntungkan bagi percetakan Hartevelt selaku pihak pemodal.

\section{Kisah Bromartani dan Kondisi Pers Hari Ini}

Tisah singkat "Sang Pionir" yang diuraikan di atas, mungkin bias ditarik benang
merahnya terhadap kondisi pers hari ini. Terutama tentang kisah berakhirnya penerbitan Bromartani. Melihat surat kabar hari ini-dalam hal ini surat kabar cetakyang mulai kehilangan daya tariknya di mata generasi milineal yang lebih doyan menikmati media daring. Bahkan satu per satu sudah mulai berhenti terbit.

Menurut Muhammad Sufyan dalam opininya "Berapa Lama Lagi Usia Koran di Indonesia?" (Harian Kompas, 7 Juli 2017) menjabarkan beberapa korban yang mulai berjatuhan seperti, Koran Sindo, Galamedia (koran regional grup Pikiran Rakyat), edisi hari minggu Koran Tempo (koran Tempo Media Group), Sinar Harapan, Jakarta Globe, Harian Bola, Majalah Horison, serta beberapa dari grup sekaliber Kompas Gramedia Group (KKG) (Kawanku, Sinyal, Chip, Chip Foto Video, What Hi Fi, Auto Expert, Car and Turning Guide, dan Motor.

Melihat merosotnya ketertarikan pada media cetak serta data melonjak data pengguna media daring. Berdasarkan pada hitungan statistik, Muhammad Sufyan memprediksi usia media cetak Indonesia hanya bertahan sekitar 10,6 tahun lagi terhitung dari Juli 2017. Jika prediksi tersebut benar, tepat tahun 2018 Indonesia akan kehilangan media cetak secara total. Sebagai penikmat pers dan sejarah pers, penulis berharap prediksi tersebut tidak benar-benar terjadi, $\left(^{*}\right)$ 